Жемела Г. П., доктор сільськогосподарських наук, професор, Курочка А. О., аспірант *

Полтавська державна аграрна академія

\title{
ВПЛИВ ПОПЕРЕДНИКІВ НА ЕЛЕМЕНТИ СТРУКТУРИ ВРОЖАЙНОСТІ ТА ЯКІСТЬ ЗЕРНА ПШЕНИЦІ ОЗИМОЇ ЗАЛЕЖНО ВІД СОРТОВИХ ВЛАСТИВОСТЕЙ
}

\section{Рецензент - доктор сільськогосподарських наук, професор П. В. Писаренко}

\begin{abstract}
Розглянуто вплив попередників на елементи структури врожайності: кількість продуктивних стебел на $1 \mathrm{M}^{2}$, кількість зерен у колосі, масу зерна в колоci, масу 1000 зерен, натуру і склоподібність різних за біологічними властивостями сортів пшениці м'якої озимої. Найоптимальніші показники елементів структури врожайності були у сортів Землячка, Володарка, Добірна. Встановлено, щз найкращими попередниками були горох та однорічні бобові трави. Краші фізичні показники якості зерна були у сортів Землячка, Володарка і Добірна.
\end{abstract}

Ключові слова: пшениия озима, сорт, попередники, урожсайність, натура зерна, склоподібність.

Постановка проблеми. Пшениця займає провідне місце серед зернових культур. Це пояснюється тим, що з іiі зерна виготовляють безліч продуктів харчування, головним із яких є хліб. 3 того часу, коли людина навчилася його виготовляти, розпочалося визначення якості зерна.

Отримання зерна, що відповідає вимогам світових стандартів, - одне 3 найважливіших завдань усіх працівників агропромислового комплексу. На даний час науковців не може задовольнити просте збільшення урожайності пшениці озимої: на перше місце завжди виступають якісні показники сільськогосподарської продукції. Потрібно, щоб у зерні містилася необхідна кількість певних білків і вуглеводів, щоб були досягнуті високі показники щодо властивостей тіста, а в кінцевому результаті випечений збалансований за поживними якостями хліб.

Однак перш ніж здобути ці вищезазначені показники якості, потрібно пройти тривалий шлях, що включає цілий комплекс агротехнічних заходів $[4,5]$.

Аналіз основних досліджень і публікацій, у яких започатковано розв'язання проблеми. Формування високої та сталої врожайності пшениці доброї якості можливе лише за повної взаємодії рослинних угрупувань 3 умовами навко- лишнього середовища. Основні групи факторів, що визначають продуктивність пшениці, - генетично зумовлені властивості того чи іншого сорту, умови вирощування (рівень агротехніки, забезпеченість рослин всіма необхідними елементами живлення та грунтово-кліматичний режим вегетаційного періоду).

Пшениця озима, порівняно з іншими зерновими, найбільш вимоглива до попередників. Особливо зменшується продуктивність пшениці за вирощування іiі після пшениці чи інших зернових. Беззмінне вирощування призводить до збільшення забур'яненості посівів, особливо пристосованими до спільного росту бур'янами. Часте повернення на поле рослин одного виду призводить до масового нагромадження у грунті збудників різних хвороб, поширенню яких сприяють заражені рослинні рештки попередньої культури. Для оздоровлення грунту необхідно висівати стійкі до даних хвороб культури [3].

Усі культури, після яких сіють пшеницю озиму, за строком висушування ними грунту на час збирання поділяються на три групи: ті, що мають достатні запаси води в грунті (кукурудза, вівсяно-горохові суміші); ті, які залишають відносно великі запаси води, але тільки в глибинних шарах грунту (зернобобові культури) й ті, що найбільше висушують грунт (зернові колосовi) [2].

Польові культури по-різному діють і на структуру грунту. Позитивно впливає на іiї формування коренева система багаторічних трав. Поліпшується структура грунту внаслідок впливу таких трав на один-два роки. Кількість водостійких агрегатів в орному шарі надзвичайно динамічна. Під впливом культур і обробітку накопичується органічна речовина як фонд для утворення клейкого матеріалу. Джерелом цієї речовини в грунтах насамперед є культурні рослини [1].

\footnotetext{
* Керівник - доктор сільськогосподарських наук, професор Г. П. Жемела
} 
Їхній вплив на утворення водостійких агрегатів залежить від могутності й характеру кореневих систем, кількості та якості органічних решток, впливу на грунтову мікрофлору, тривалості росту на полі, рівня врожайності, агротехніки й умов мінералізації органічних решток протягом вегетації та в післязбиральний період. Тому цілком зрозуміло, що попередник має важливе значення для пшениці озимої.

Найсприятливіші умови для цього створюються в полі чорного пару. Після зайнятих парів залишається тривалий післязбиральний період, протягом якого випадають дощі, тому тут успішно відбуваються процеси, пов'язані з утворенням доступних для рослин форм поживних речовин. Непарові попередники пшениці озимої в цьому відношенні поступаються парам. Вони пізно звільняють поле (липень - серпень), у цей час стоїть засушлива погода, в грунті уповільнюються мікробіологічні та фізико-хімічні процеси $[2,3]$.

Мета дослідження та методика їхнього проведення. Метою наших досліджень було вивчення впливу попередників на якість зерна пшениці озимої та на елементи структури врожайності.

Дослідження проводили в 2009-2010 рр. на базі ТОВ «Дукла» Полтавського району Полтавської області. Господарство розташоване в зоні нестійкого зволоження. Середньорічна кількість опадів становить 490-500 мм, грунтовий покрив - чорнозем типовий малогумусний. Вміст гумусу - 4,5-5,5 \%, сума активних температур - у межах $2500-3000{ }^{\circ} \mathrm{C}$.

Об'єктом досліджень були сорти пшениці озимої:

- Землячка - різновидність еритроспермум, сорт створений внаслідок схрещування лінії Еритроспермум 8792/91 із сортом Вікторія одеська (еліта);

- Володарка - різновидність лютесценс, сорт створений Миронівським інститутом пшениці ім. В. М. Ремесла (еліта);

- Добірна - різновидність лютесценс, сорт створений Миронівським інститутом пшениці ім. В. М. Ремесла (еліта);

- Смуглянка - різновидність лютесценс, сорт створений Миронівським інститутом пшениці ім. В. М. Ремесла (еліта).

Зразки відбирали 3 ділянки площею $0,25 \mathrm{~m}^{2}$ в чотирьохразовій повторності в фази кущіння, виходу в трубку, колосіння. Для визначення фізичних показників якості зерна пшениці озимої зразки відбирали у фазі молочного, тістоподібного стану та в повну стиглість зерна.
Результати досліджень. За результатами наших досліджень, були встановлені середні показники елементів структури врожайності пшениці озимої (табл. 1).

Дані дослідження показали, що кількість зерен у колосі змінювалася від 24 шт. (сорт Добірна, попередник - соняшник) до 38 шт. (сорт Володарка, попередник - горох; сорт Смуглянка, попередник - кукурудза на силос). Ці зміни свідчать про те, що на кількість зерен у колосі впливають не тільки попередники, а й погодні умови в осінньо-зимовий період та сортові особливості.

Маса зерна 3 колоса $є$ важливим показником, яка також залежить від попередників. Найбільша маса зерна 3 колоса була у сорту Володарка $\mathrm{i}$ становила 1,9 г. Аналогічні показники отримані й у сорту Землячка (попередники - горох, однорічні трави), і у сорту Добірна (попередники однорічні трави, кукурудза на силос).

Формування кількості продуктивних стебел один із найважливіших процесів, від якого залежить рівень врожайності. Так, найбільша кількість продуктивних стебел спостерігалась у сорту Землячка і становила 582 шт./м² (попередник - однорічні трави), а найменша у сорту Добірна - 410 шт./M ${ }^{2}$ (попередник - соняшник).

Що стосується формування біологічної врожайності, то найбільшою вона була у сортів Володарка, Землячка, Смуглянка, відповідно, попередниками яких були горох, однорічні трави та кукурудза на силос. Найменша врожайність виявилась у сорту Смуглянка, - попередник соняшник (табл. 1).

Отже, горох є найкращим попередником для пшениці озимої, після якого формується найбільша врожайність. Дещо меншою вона була після ріпаку озимого, однорічних бобових трав, кукурудзи на силос. Найгіршим попередником виявився соняшник.

Попередники суттєво впливають на натуру, склоподібність та масу 1000 зерен (табл. 2).

За роки досліджень на формування фізичних показників якості зерна значно впливали попередники. Згідно з одержаними нами даними, маса 1000 зерен знаходилася в межах від 30,0 г до 49,0 г. Найбільша маса 1000 зерен була у сорту Землячка (попередник - однорічні трави), а найменша - у сорту Смуглянка.

Як показали наші дослідження, найбільшу натуру мав сорт Землячка. Відповідно, кращим попередником стали однорічні трави, а найгірше себе проявив сорт Смуглянка (попередник - соняшник). 
СІЛЬСЬКЕ ГОСПОДАРСТВО. РОСЛИННИЦТВО

\section{1. Вплив попередників на елементи структури врожайності}

\begin{tabular}{|c|c|c|c|c|c|c|c|c|c|}
\hline \multirow{3}{*}{ Сорт } & \multirow{3}{*}{ Попередники } & \multicolumn{2}{|c|}{$\begin{array}{c}\text { Кількість зерен } \\
\text { у колосі, шт. }\end{array}$} & \multicolumn{2}{|c|}{$\begin{array}{l}\text { Маса зерна } \\
\text { з колоса, г }\end{array}$} & \multicolumn{2}{|c|}{$\begin{array}{c}\text { Кількість } \\
\text { продуктивних } \\
\text { стебел, шт./м² }\end{array}$} & \multicolumn{2}{|c|}{$\begin{array}{c}\text { Біологічна } \\
\text { врожайність, } \\
\text { ц/га }\end{array}$} \\
\hline & & \multicolumn{8}{|c|}{ Роки досліджень } \\
\hline & & 2009 & 2010 & 2009 & 2010 & 2009 & 2010 & 2009 & 2010 \\
\hline \multirow{6}{*}{ Смуглянка } & соняшник & 32 & 26 & 0,9 & 0,6 & 412 & 418 & 28,4 & 37,6 \\
\hline & ріпак ярий & 32 & 34 & 1,0 & 1,2 & 430 & 439 & 43,0 & 52,6 \\
\hline & $\operatorname{cog}$ & 35 & 36 & 1,4 & 1,3 & 436 & 439 & 61,4 & 57,0 \\
\hline & $\begin{array}{c}\text { кукурудза } \\
\text { на силос }\end{array}$ & 39 & 38 & 1,6 & 1,7 & 450 & 447 & 72,0 & 75,9 \\
\hline & ячмінь & 30 & 33 & 0,9 & 1,2 & 432 & 439 & 38,8 & 52,6 \\
\hline & однорічні трави & 28 & 34 & 1,3 & 1,6 & 449 & 462 & 58,2 & 73,9 \\
\hline \multirow{6}{*}{ Добірна } & однорічні трави & 32 & 37 & 1,6 & 1,8 & 515 & 520 & 82,4 & 93,6 \\
\hline & $\operatorname{cog}$ & 30 & 36 & 1,0 & 1,2 & 470 & 452 & 47,0 & 52,4 \\
\hline & соняшник & 24 & 31 & 0,7 & 1,2 & 427 & 448 & 29,8 & 53,7 \\
\hline & ріпак ярий & 26 & 30 & 1,2 & 1,4 & 418 & 423 & 50,1 & 59,2 \\
\hline & $\begin{array}{c}\text { кукурудза } \\
\text { на силос }\end{array}$ & 30 & 32 & 1,6 & 1,7 & 524 & 522 & 83,8 & 88,7 \\
\hline & ячмінь & 28 & 30 & 1,2 & 1,0 & 421 & 439 & 50,5 & 43,9 \\
\hline \multirow{4}{*}{ Володарка } & $\begin{array}{c}\text { кукурудза } \\
\text { на силос }\end{array}$ & 32 & 38 & 1,6 & 1,6 & 528 & 572 & 84,4 & 83,5 \\
\hline & ріпак ярий & 33 & 39 & 1,2 & 1,5 & 475 & 474 & 57,0 & 71,1 \\
\hline & горох & 38 & 47 & 1,7 & 1,9 & 510 & 517 & 86,7 & 98,2 \\
\hline & ячмінь & 30 & 29 & 1,4 & 1,2 & 460 & 464 & 64,4 & 55,6 \\
\hline \multirow{4}{*}{ Землячка } & coя & 36 & 36 & 1,4 & 1,5 & 468 & 459 & 65,5 & 68,8 \\
\hline & соняшник & 27 & 30 & 1.3 & 1,0 & 426 & 432 & 55,3 & 42,6 \\
\hline & горох & 31 & 35 & 1,6 & 1,7 & 574 & 560 & 91,8 & 95,2 \\
\hline & днорічні трави & 36 & 53 & 1,6 & 1,5 & 580 & 582 & 92,8 & 87,3 \\
\hline
\end{tabular}

2. Фізичні показники якості зерна пшениці озимої залежно від сортових властивостей ма попередників

\begin{tabular}{|c|c|c|c|c|c|c|c|}
\hline \multirow{2}{*}{ Сорт } & \multirow{2}{*}{ Попередник } & \multicolumn{2}{|c|}{ Мaca 1000 зерен, Г } & \multicolumn{2}{|c|}{ Натура зерна, г/л } & \multicolumn{2}{|c|}{ Склоподібність, \% } \\
\hline & & $2009 \mathrm{p}$. & $2010 \mathrm{p}$ & 2009 p. & $2010 \mathrm{p}$. & 2009 p. & 2010 p. \\
\hline \multirow{6}{*}{ Смуглянка } & соняшник & 30 & 32 & 716 & 747 & 34 & 39 \\
\hline & ріпак ярий & 30 & 34 & 724 & 774 & 32 & 37 \\
\hline & $\operatorname{cog}$ & 36 & 39 & 718 & 764 & 28 & 34 \\
\hline & $\begin{array}{c}\text { кукурудза } \\
\text { на силос }\end{array}$ & 37 & 40 & 729 & 745 & 22 & 32 \\
\hline & ячмінь & 32 & 34 & 741 & 740 & 32 & 40 \\
\hline & однорічні трави & 33 & 42 & 749 & 765 & 37 & 44 \\
\hline \multirow{6}{*}{ Добірна } & однорічні трави & 36 & 44 & 762 & 776 & 22 & 37 \\
\hline & соя & 30 & 33 & 742 & 763 & 20 & 43 \\
\hline & соняшник & 30 & 32 & 761 & 779 & 20 & 36 \\
\hline & ріпак ярий & 34 & 37 & 764 & 772 & 38 & 53 \\
\hline & $\begin{array}{c}\text { кукурудза } \\
\text { на силос }\end{array}$ & 38 & 42 & 762 & 772 & 30 & 34 \\
\hline & ячмінь & 31 & 34 & 756 & 762 & 28 & 39 \\
\hline \multirow{4}{*}{ Володарка } & $\begin{array}{c}\text { кукурудза } \\
\text { на силос }\end{array}$ & 42 & 44 & 714 & 740 & 24 & 30 \\
\hline & ріпак ярий & 40 & 43 & 780 & 788 & 36 & 45 \\
\hline & горох & 42 & 46 & 770 & 789 & 42 & 45 \\
\hline & ячмінь & 34 & 38 & 752 & 749 & 30 & 42 \\
\hline \multirow{4}{*}{ Землячка } & $\operatorname{cog}$ & 36 & 39 & 764 & 772 & 28 & 34 \\
\hline & соняшник & 40 & 42 & 760 & 765 & 34 & 39 \\
\hline & горох & 44 & 48 & 772 & 810 & 48 & 50 \\
\hline & однорічні трави & 46 & 49 & 778 & 814 & 45 & 53 \\
\hline
\end{tabular}


Склоподібність зерна залежала від року досліджень: так, 2010 рік за показниками був кращим за попередній.

Найвищі дані одержані у сорту Землячка, попередниками якого були однорічні трави та горох (склоподібність, відповідно, 53 \% і 50 \%).

Висновки. За результатами проведених досліджень можна зазначити, що найкращими попередниками для пшениці озимої були горох та

\section{БІБЛІОГРАФІЯ}

1. Годулян И. С. Озимая пшениця в севообороте. - Днепропетровск: Промінь. - 1974. - 175 с.

2. Жемела Г. П., Мусатов А. Г. Агротехнічні основи підвищення якості зерна. - К.: Урожай, 1989. - 160 c.

3. Лихочвор В. В. Рослинництво. - К.: Центр навчальної літератури, 2004. $-808 \mathrm{c}$. однорічні бобові трави.

Найоптимальніші показники елементів структури врожайності були у сортів Землячка, Володарка, Добірна.

За фізичними показниками якості зерна можна виділити сорти пшениці озимої: Землячку (за масою 1000 зерен i натурою), Володарку i Добірну (за склоподібністю).

4. Пшеницы мира / Под. ред. Д. Д. Брежнева; сост. В.Ф. Дорофеев. - К.: Колос, 1976. - 487 с. 5. Жемела Г. П., Шемавньов В. І., Маренич М. М. [ma ін.]. Технологія зберігання та переробки продукції рослинництва: Навч. посіб. Дніпропетровськ, 2005. - 248 с. 